\title{
Experimental Investigation of Double Slope Solar Still for the Climatic Condition of Sultanpur
}

\author{
Raj Vardhan Prasad Patel ${ }^{\# 1}$, Anil Kumar ${ }^{* 2}$ \\ ${ }^{\#}$ Master Scholar, \\ Department of Mechanical Engineering KNIT Sultanpur, U.P. (India) Pin-228118 Tel: +91 9458581003 \\ ${ }^{1}$ rvpatel.knit@gmail.com \\ *Assistant Professor \\ Department of Mechanical Engineering KNIT Sultanpur, U.P. (India) Pin-228118 Tel: +91 9453290647 \\ 2 anilap.knit@gmail.com
}

\begin{abstract}
A single basin double slope solar still of $1 \mathbf{~ m}^{2}$ basin area is fabricated from an acrylic sheet of $3.5 \mathrm{~mm}$. The condensing glass covers of $3.5 \mathrm{~mm}$ thickness with $30^{\circ}$ tilt angle are used. In the present work, an attempt has been made to investigate the effect of the various parameters on the productivity of solar still like water depth, wind velocity, solar radiation, etc. The solar still experimentally tested under the climatic condition of Sultanpur $\left(26.26^{\circ}\right.$ North, $82.07^{\circ}$ East) in the month of March and April. For the present study, the experiments are conducted for both orientation East-West and North-South of solar still. The hourly temperature has been recorded for water, basin liner, and glass surfaces. It is seen that the production rate increases with increase in wind velocity and cooling of glass covers. The production of $75 \mathrm{ml}$ (from 16:30 hrs. to 17:00 hrs.) found for the temperature difference of $9.2^{\circ} \mathrm{C}$ after cooling the covers. The yield is $20.46 \%$ higher when basin water depth is $2 \mathrm{~cm}$ as compared to $4 \mathrm{~cm}$ basin water depth from 8:00 hrs. to 17:00 hrs. The results indicated that the production of distilled water increases with the increase in wind velocity, cooling the glass covers and the decrease in water depth.
\end{abstract}

Keyword - Solar still, acrylic, solar desalination, East-West and North-South orientation.

\section{INTRODUCTION}

Next to the oxygen, the fresh water is essential for sustaining the human life. About $97 \%$ of water available earth are brackish or saline and $2 \%$ of water available in the form glaciers. Thus, only $1 \%$ of the earth, water are potable i.e. drinkable [1-4]. Much of the world's population does not have access to safe drinking water, which is the main cause of waterborne diseases that kill on the average more than 6 million children each year. Hence, we must find new and reasonable ways of producing pure water from brackish/saline water. Solar distillation is a good method for water purification and requires solar energy for its operation which is environmentally friendly and free [5-7]. The construction and operation of a solar still are very simple. There is a black painted basin, which contains brackish water and it's covered by a transparent cover. The incident solar radiation falls on the black pained basin and the brackish water gets evaporated and it's condensed on condensing cover and gets collected [8-10].

A.A. Al-Karaghouli and W.E. Alnaser reported that the production of a double slope, solar still is greater than the single basin solar still [11]. M.M. Morad et al. has conducted an experiment and reported that the passive solar still production rate is increased when there is cooling of condensing cover [12]. T. Rajaseenivasan and K. Kalidasa Murugavel have carried out their experiment and concluded that the production rate is maximum when basin water depth is minimum. They have also reported that the production of a double basin solar still is higher than the single basin solar still [3]. M. Zeroual et al. has presented the result of an experiment carried out with a solar still that the average daily output of a double slope, solar still is improved by $11.82 \%$ when the north glass is cooled by water on flowing on it [13]. V.K. Dwivedi and G.N. Tiwari have reported that the thermal efficiency of double slope passive solar still is higher than the double slope active solar still [14]. Margarita Castillo-Tellez et al. conducted an experiment and based on experimental results they concluded that the rate of production of solar still will be increased when wind velocity increase up to a certain limit, they reported that the wind velocity should not be greater than $5.5 \mathrm{~m} / \mathrm{s}$ for their experimental setup [15]. G.N.Tiwari et al. reported that the East-West orientation of DSSS has a greater production rate than the single slope, solar still in summer condition because the sun is at a higher position in summer condition [16].

It is clear from the above literature review numerous studies were published on a double slope solar still desalination system. The main objective of doing this project is to study the effects of various parameters like water depth, wind velocity, cooling of condensing glass covers and solar radiation etc. on the productivity of DSSS for the climatic condition of Sultanpur and also to study the orientation is good for the Sultanpur climatic condition. 


\section{A. Experimental Setup}

\section{EXPERIMENTAL}

The acrylic-based double slope passive solar still is designed and fabricated for the experimental investigation of the climatic condition of Sultanpur. The schematic diagram of the experimental setup is shown in Fig. 1 and the real experimental setup is shown in Fig.2. The black acrylic is chosen for the basin material so that it can absorb maximum solar radiation. The single basin, double slope, solar still is made airtight and the area is taken as $1 \mathrm{~m} 2$ for a basin and the height of the basin is taken as $10 \mathrm{~cm}$. The overall size of the inner basin of the experimental setup is $1 \mathrm{~m} \times 1 \mathrm{~m} \times 0.01 \mathrm{~m}$. Plywood of $12 \mathrm{~mm}$ thickness is used for the insulating the solar still so that there is a maximum utilization of solar radiation in the solar still. Therefore, the outer basin size is $1.31 \mathrm{~m}$ $\times 1.31 \mathrm{~m} \times 0.0255 \mathrm{~m}$. A glass of $4 \mathrm{~mm}$ thickness is used to cover the top of the basin and glasses are placed at the $30^{\circ}$ angle with the horizontal. The V-shaped drainage made from aluminium is provided for the collection of distilled water from the solar still and the water is collected into a jar. The temperature sensors are used to measure the temperature at the different places of a solar still like basin liner temperature, basin water temperature, water vapour temperature, inner glass temperature, etc. The solar radiation data are taken from SRRA station which is installed at KNIT, Sultanpur and anemometer are used for taking the wind velocity data. The Pyranometer of SRRA station is shown in Fig.3.

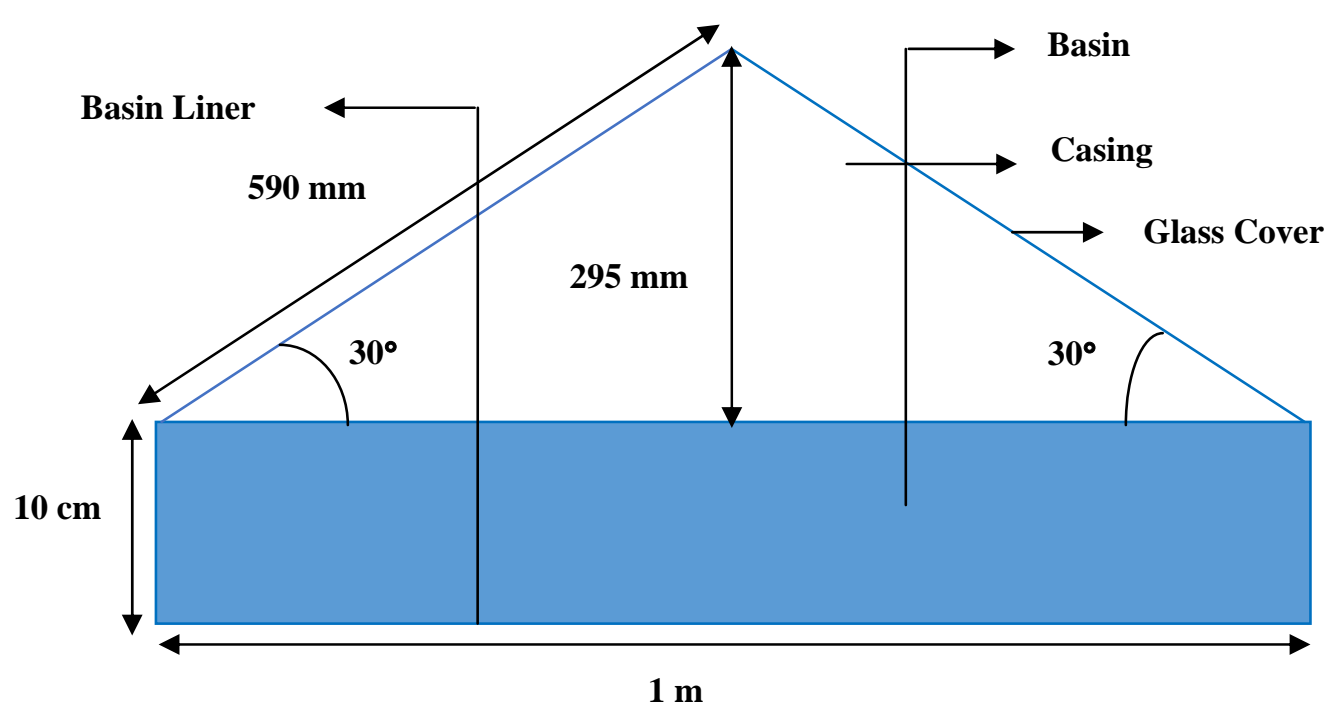

Fig. 1. A Schematic diagram of Solar Still

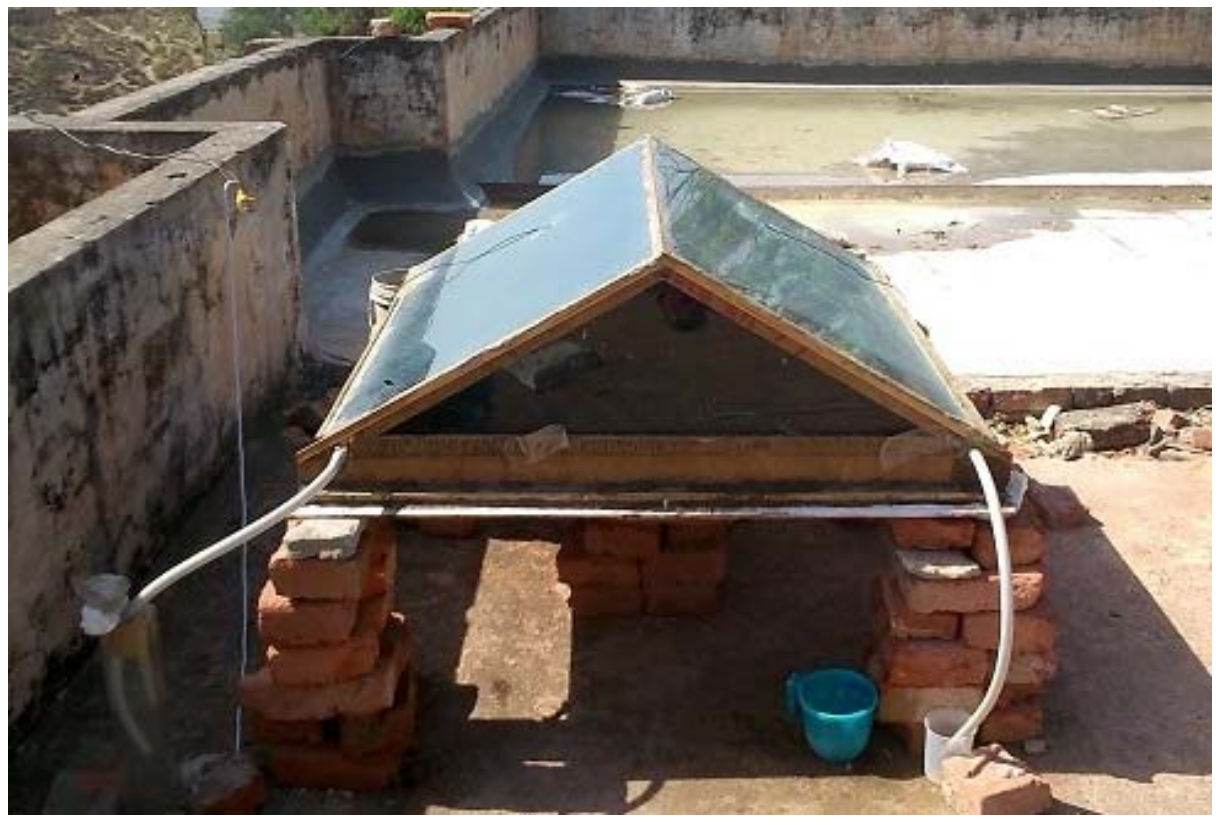

Fig. 2. Real Experimental Setup of Solar Still 


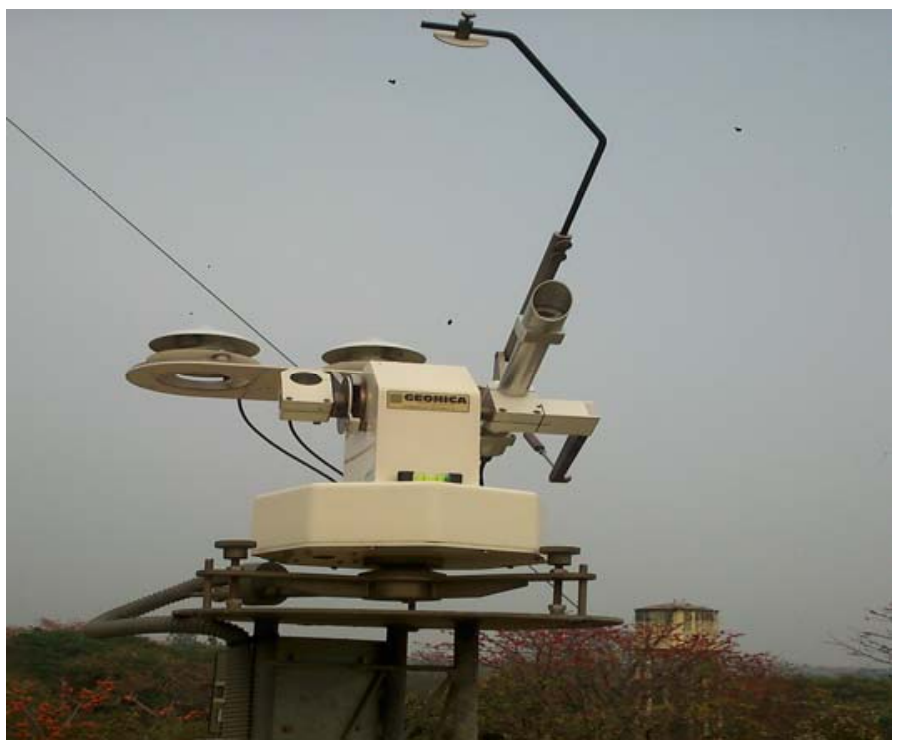

Fig. 3. Pyranometer of SRRA Station, KNIT Sultanpur

\section{B. Experimental Procedure}

The experiential tests are conducted at the roof of KNIT, Sultanpur (U.P.) India $\left(26.26^{\circ} \mathrm{N}, 82.07^{\circ} \mathrm{E}\right)$. The experiments are conducted from March 2016 to April 2016, during this period all the data like solar radiation, wind velocity ambient temperature, etc. are taken from SRRA station which is installed at KNIT, Sultanpur Building. Among all the reading some typical readings are taken for clear days. The readings are taken during the day as well as night-time. The solar still are placed both orientations for reading, i.e. E-W and N-S. The basin water depth also changes in experiments. The solar radiation data are taken from SRRA station Sultanpur which is installed at Knit, Sultanpur academic building where the experimental setup is placed. The basin water, ambient, glass cover, vapour and basin liner temperature are recorded hourly with the help of temperature sensors. There are seven temperature sensors are used in the experimental setup. The wind velocity is also recorded by an anemometer. Hourly and daily distillate output is measured with the help of measuring jar.

\section{Measuring Devices}

1) Measurement of Temperature: The Digital Mini LCD Temperature Thermometer with Probe sensors are used to measure the temperatures at various locations of the still. There are 7 temperature sensors are used for taking the readings of temperature at the different location in the experimental setup. The two sensors are placed at the top of the glass covers for measuring the temperature of the outer surfaces of glass covers and two sensors are placed inside the casing on the glass for measuring the temperature of the inside surfaces of the glass. There is one sensor used to measure the temperature of water present in the basin and one sensor is used to measure the temperature of basin liner. For measuring the water vapour temperature, the one sensor is used. The range of this temperature sensor is from $-50^{\circ} \mathrm{C}$ to $110^{\circ} \mathrm{C}$.

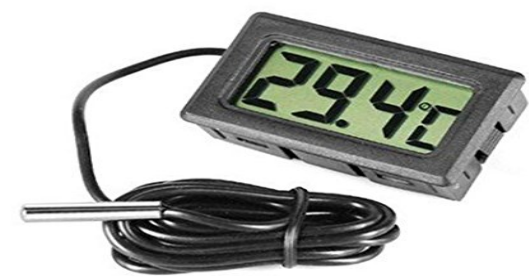

Fig. 4. Digital mini LCD temperature thermometer with probe

2) Measurement of Wind Speed: The Generic GM816 LCD Digital Wind Speed, Temperature Measure Gauge Anemometer is used to measure the wind velocity. The wind speed plays a vital role in cooling of glass covers of solar still which affect the productivity of solar still. The anemometer which is used for measuring the 32 wind speed has a range of $0-30 \mathrm{~m} / \mathrm{s}$ with an accuracy of $\pm 5 \%$. The threshold value of this anemometer is $0.1 \mathrm{~m} / \mathrm{s}$. The velocity reading is also taken from SRRA station. 


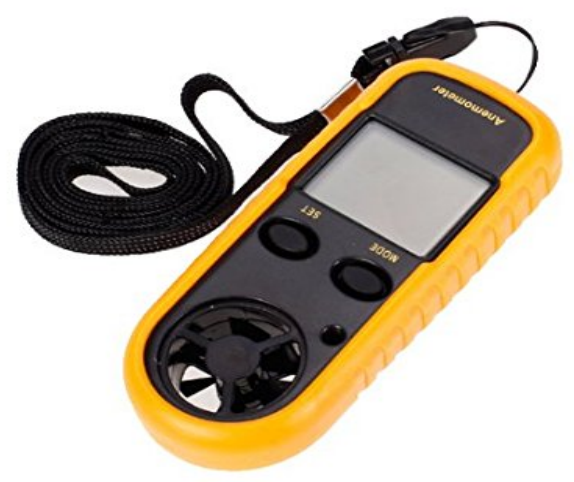

Fig. 5. Generic GM816 LCD digital wind speed temperature measure gauge anemometer

3) Measurement of Solar Radiation: The global solar radiation incident on a horizontal surface is measured from a Pyranometer which is installed by SRRA. The solar radiation data are taken from SRRA station, Sultanpur. The Pyranometer which is used for solar radiation data shown in Fig.3.

4) Measurement of $\mathrm{pH}$ and TDS: Digital $\mathrm{PH}$ Tester Meter used to measure the $\mathrm{pH}$ of basin water as well as distillate water. PH meter has the range of $0-14.0 \mathrm{pH}$ with the resolution of $0.1 \mathrm{pH}$ and accuracy of \pm 0.2 $\mathrm{pH}$ (for operating temperature $0^{\circ} \mathrm{C}-50^{\circ} \mathrm{C}$ ).

A digital TDS Meter of Range 0-9,990ppm with Accuracy of $\pm 2 \%$ has been used for measuring the TDS of basin water and distillate water.

\section{A. Heat Transfer in Solar still}

\section{THERMAL MODELING}

The heat transfer in solar distillation system can be classified in terms of internal and external heat transfer modes. The different heat interactions in the solar distillation unit have been explained below.

1) Internal heat transfer: The internal heat transfer mode, i.e. the heat exchange from water surface to glass cover inside the solar still distillation unit is governed by radiation, convection and evaporation.

> Convective heat transfer: The heat transfer is taking place across the air, which is inside the solar still. As our system is airtight, therefore, there is no external velocity provided to the inside air for causing heat transfer. The air is humid because of vapour evaporating from the water surface, the heat transfer is due to the buoyancy only i.e. free convection heat transfer occurs inside the still casing.

The rate of convective heat transfer $\left(\dot{q}_{c w}\right)$ from water surface to condensing glass cover is given by-

$$
\dot{q}_{c w}=h_{c w}\left(T_{w}-T_{g}\right)
$$

The value of convective heat transfer coefficient is depending upon the following parameters-

- $\quad$ Operating temperature range of still and physical properties of the fluid at this operating temperature.

- Condensing cover geometry.

- $\quad$ Flow characteristics of the fluid.

$>$ Evaporative heat transfer: The evaporative heat transfer occurs between the water surface and the glass inner surface of the solar distillation unit.

The rate of evaporative heat transfer $\left(\dot{q}_{e w}\right)$ from water surface to glass cover surface is given by-

$$
\dot{q}_{e w}=h_{e w}\left(T_{w}-T_{g}\right)
$$

$>\quad$ Radiative heat transfer coefficient: The rate of radiative heat transfer $\left(\dot{q}_{r w}\right)$ from water surface to glass cover for these infinite parallel surfaces is given by-

$$
\dot{q}_{r w}=\varepsilon_{\text {eff }} \sigma\left[\left(T_{w}+273\right)^{4}-\left(T_{g}+273\right)^{4}\right]
$$


The rate of radiative heat transfer is also given by-

$$
\dot{q}_{r w}=h_{r w}\left(T_{w}-T_{g}\right)
$$

The $\left(h_{r w}\right)$ is the radiative heat transfer coefficient from water surface to the glass cover and it's given by-

$$
\dot{q}_{r w}=\varepsilon_{e f f} \sigma\left[\left(T_{w}+273\right)^{2}+\left(T_{g}+273\right)^{2}\right]\left[T_{w}+T_{g}+546\right]
$$

(by comparing above equations)

Where $\varepsilon_{\text {eff }}=$ Effective emissivity of water and glass surface

$$
\sigma=\text { Stefan-Boltzmann constant }=5.67 \times 10^{-8} \mathrm{~W} / \mathrm{m}^{2} \mathrm{~K}
$$

$>\quad$ External heat transfer: The external heat transfer is primarily governed by conduction, convection and radiation process, which are independent of each other. These heat transfers occur outside the solar distiller, from the glass cover and the bottom and side insulation.

- Top loss coefficient: Due to the small thickness of glass cover the temperature in the glass may be assumed to be uniform. The external heat transfer radiation and convection losses from glass to ambient are expressed as-

$$
\begin{aligned}
& \dot{q}_{g}=\dot{q}_{r g}+\dot{q}_{c g} \\
& \dot{q}_{r g}=\sigma\left[\left(T_{g}+273\right)^{4}-\left(T_{s k y}+273\right)^{4}\right] \\
& \dot{q}_{r g}=h_{r g}\left(T_{g}-T_{a}\right)
\end{aligned}
$$

Comparing the above equations, we get-

$$
h_{r g}=\frac{\varepsilon_{g} \sigma\left[\left(T_{g}+273\right)^{4}-\left(T_{s k y}+273\right)^{4}\right]}{\left(T_{g}-T_{a}\right)}
$$

$$
\text { Where } T_{\text {sky }}=T_{a}-6
$$

And the rate of convective heat transfer from the glass surface to ambient is given by-

$$
\dot{q}_{c g}=h_{c g}\left(T_{g}-T_{a}\right)
$$

On substituting the value of $\left(\dot{q}_{r g}\right)$ and $\left(\dot{q}_{c g}\right)$ in equation (9) we get-

$$
\dot{q_{g}}=h_{1 g}\left(T_{g}-T_{a}\right)
$$

$$
\text { Where } h_{1 g}=h_{r g}+h_{c g}
$$

The expression for $\left(h_{1 g}\right)$ is given by-

$$
h_{1 g}=5.7+3.8 \mathrm{~V} \quad \text { (Watmuff et al.) }
$$

And $h_{c g}=2.8+3 \mathrm{~V}$

- $\quad$ Bottom and side loss coefficient: Heat is also lost from the water in the basin to the ambient through the insulation subsequently by convection and radiation from the bottom or side surface of the basin. The bottom loss coefficient $\left(U_{b}\right)$ can be written as-

$$
U_{b}=\left[\frac{1}{h_{w}}+\frac{1}{h_{b}}\right]^{-1}
$$


The side loss coefficient $\left(U_{e}\right)$ can be expressed as

$$
U_{e}=\frac{U_{b} A_{S S}}{A_{S}}
$$

Here $A_{S S}$ is the surface area in contact with water and $A_{S}$ is the area of the basin of the distiller. $A_{S S}$ is very small in comparison to $A_{S}$, for small water depth.

The rate of heat loss per $\mathrm{m}^{2}$ from the basin liner to ambient can be written as,

$$
\dot{q}=h_{b}\left(T_{W}-T_{g}\right)
$$

Where $h_{b}=\left[\frac{L_{i}}{K_{i}}+\frac{1}{h_{c b}+h_{r b}}\right]^{-1}$

B. Dunkle's model

Dunkle has developed an equation for evaluation of the internal heat transfer coefficient which is quite popular and is given below -

The convective heat transfer coefficient is given by [31]

$$
h_{c w}=0.0884\left(\Delta T^{*}\right)^{\frac{1}{3}}
$$

Where $\Delta T^{*}=\left[\left(T_{w}-T_{g}\right)+\frac{\left(P_{w}-P_{g}\right)\left(T_{w}+273.15\right)}{268.9 \times 10^{3}-P_{w}}\right]$

And the evaporative heat transfer from water surface to the glass surface is given by-

$$
\dot{q_{e w}}=0.013 h_{c w}\left(P_{w}-P_{g}\right)
$$

Similar equation has also been derived by Cooper, and is given by-

$$
\dot{q}_{e w}=0.0162 h_{c w}\left(P_{w}-P_{g}\right)
$$

The above equation can be rearranged as-

$$
\dot{q_{e w}}=h_{e w}\left(T_{w}-T_{g}\right)
$$

Where $h_{e w}=16.273 \times 10^{-3} h_{c w} \frac{\left(P_{w}-P_{g}\right)}{\left(T_{w}-T_{g}\right)}$

Where $P_{w}$ and $P_{g}$ are partial saturation pressures and given by-

$$
\begin{aligned}
& P_{g}=\exp \left[25.317-\frac{5144}{\left(T_{g i}+273\right)}\right] \\
& P_{w}=\exp \left[25.317-\frac{5144}{\left(T_{w}+273\right)}\right]
\end{aligned}
$$

\section{Determination of distillate output}

The hourly distillate output per $\mathrm{m} 2$ from the solar still can be obtained as-

$$
m_{e w}=\frac{\dot{q}_{e w}}{L} 3600
$$




$$
\text { Or } m_{e w}=\frac{h_{e w}\left(T_{w}-T_{g}\right)}{L} 3600 \mathrm{~kg} / \mathrm{m}^{2} / \mathrm{h}
$$

Where $\mathrm{L}$ is latent heat of vaporization for less than $70^{\circ} \mathrm{C}$ and it is given by-

$$
L=2.4935 \times 10^{6}\left[1-9.4779 \times 10^{-4} \mathrm{~T}+1.3132 \times 10^{-7} \mathrm{~T}^{2}-4.7974 \times 10^{-9} \mathrm{~T}^{3}\right]
$$

(Fernandez and Chargoy 1990)

\section{IV.RESULTS AND DISCUSSIONS}

The temperature variation for $2 \mathrm{~cm}$ water depth for North-South as well as East-West orientation shown in Fig. 6. The basin temperature has been found higher for North-South orientation. The cumulative yield from the double slope, solar still is shown in Fig. 7. The yield is shown for $2 \mathrm{~cm}$ water depth (8 April) and $4 \mathrm{~cm}$ water depth (14 April) in the basin from 8:00 hrs. to 17:00 hrs. It is clear from Fig. that the yield is better for $2 \mathrm{~cm}$ as compared to $4 \mathrm{~cm}$ water depth in the basin. The production of distilled water is started earlier when depth is 2 $\mathrm{cm}$ because the basin water heating is faster than when depth is $4 \mathrm{~cm}$.

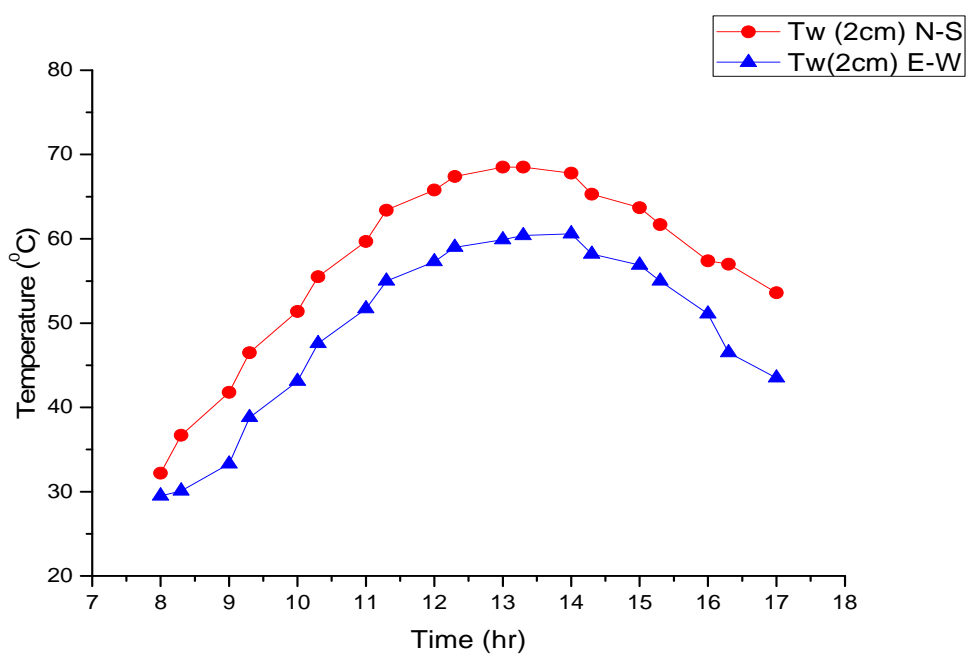

Fig. 6. Hourly temperature variation of basin water for East-West and North-South orientation

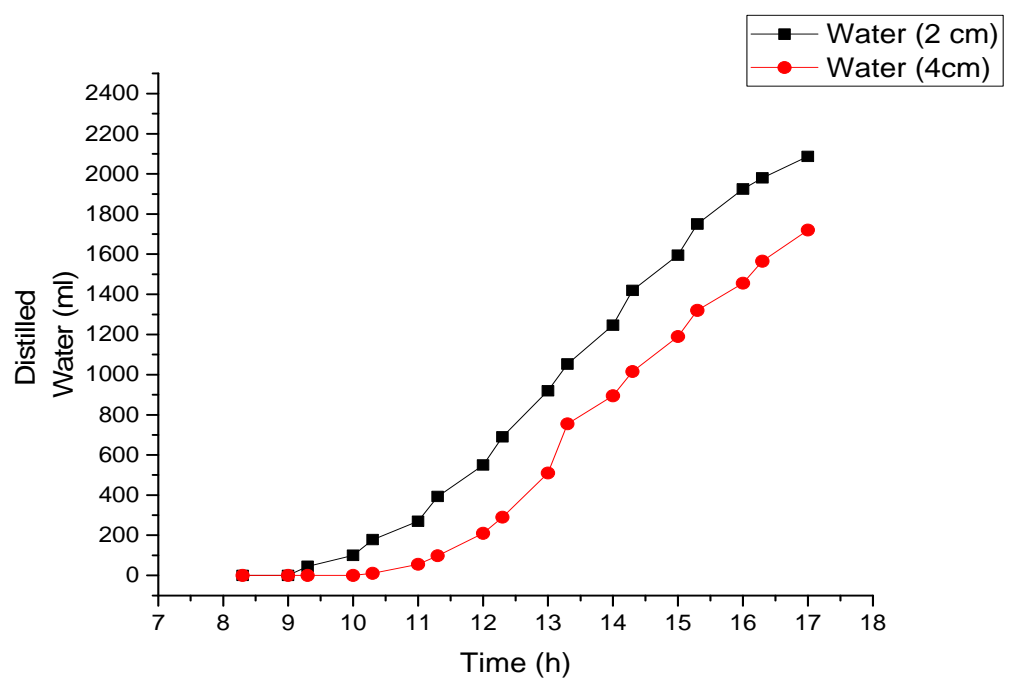

Fig. 7. Cumulative yield of DSSS for $2 \mathrm{~cm}$ and $4 \mathrm{~cm}$ water depth

The Fig. 8 shows the temperature variation of the glass inner surfaces, basin water and vapour temperature for 2 $\mathrm{cm}$ water depth on 8 April when still is placed $\mathrm{E}-\mathrm{W}$ orientation. The ambient temperature is also shown in the Fig. It can be observed in Fig. that the water temperature is more than the inner surface of east glass after 12:30 hrs. due to this, the production of water from the east side is better than the west side. 
The Fig. 9 shows the temperature variation of the glass inner surfaces, basin water and vapour temperature for $4 \mathrm{~cm}$ water depth on 14 April when still is placed E-W orientation. The sun rays only incident on the east side, up to 11:30 hrs. not on the west side, therefore, the temperature of east glass i.e. Tgi (E) is greater than Tgi (W) and after that west side temperature increases when sun rays directly incident on west glass only. The rate of increase of Tgi (E) is decreased after 11:00 hrs. because of the temperature increases due to condensation of water on the glass surface. The Tgi (W) remains higher than Tgi (E) after 11:30 hrs. because there is heat addition by condensation (basin water is heated up to a temperature from starting of experiment time to 11:00 hrs. for evaporation) as well as direct sun radiation. It is observed that at 12:30 hrs. There is no temperature difference between water and glass inner surfaces to maintain the temperature difference there is a spray of water on both glasses, therefore at 13:30 hrs. there is a decrement in glass surface temperature and due to this, the production rate is high at this point.

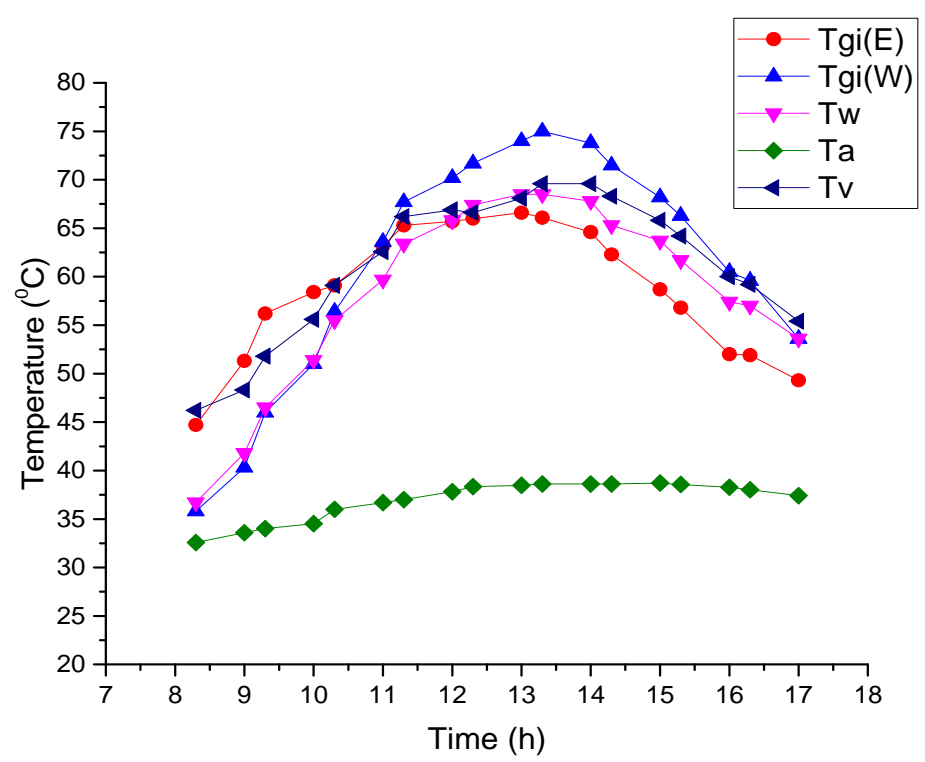

Fig. 8. Hourly temperatures variation of solar still for $2 \mathrm{~cm}$ water depth

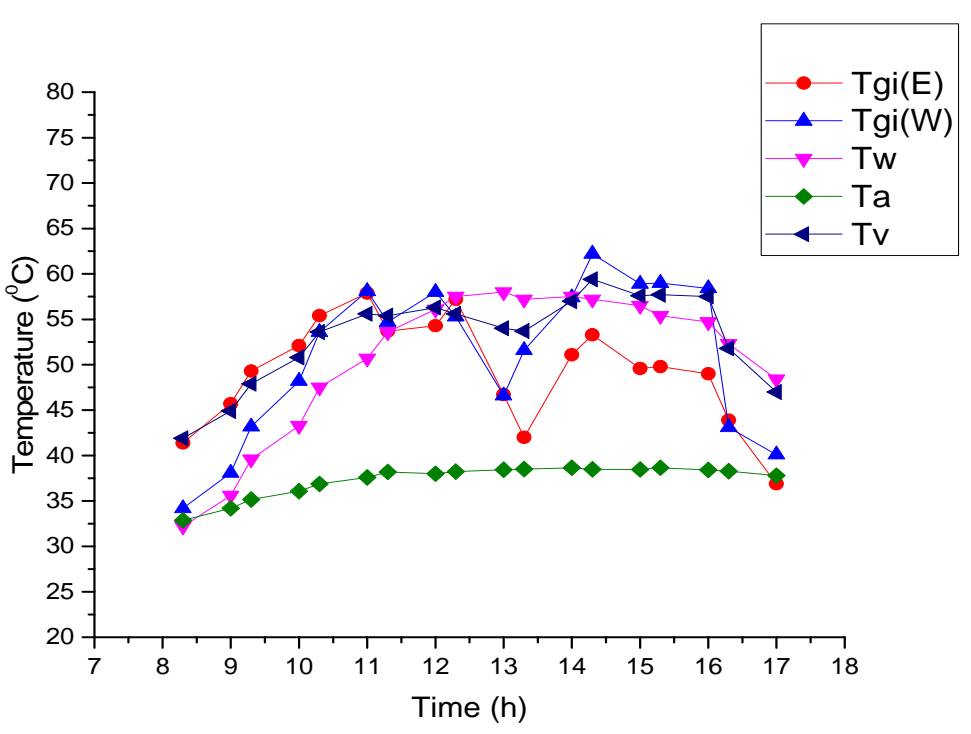

Fig. 9. Hourly temperatures variation of solar still for $4 \mathrm{~cm}$ water depth

Fig. 10 shows the cumulative water production from one side of double slope solar still. It can be noted that the production rate is increased from 12:30 hrs. to 14:00 hrs. and also from 16:00 hrs. to 17:00 hrs. because water sprays on the glass to maintain the good temperature difference between the glass surface and basin water. The spray starts at 12:40 hrs. for maintaining temperature difference and after maintaining a temperature difference of $11.3^{\circ} \mathrm{C}$ at $13: 00$ hrs. the condensation rate is good and there is a production of about $120 \mathrm{ml}$ between 13:00 hrs. and 13:30 hrs. Between 15:30 hrs. to 16:00 hrs. the production of water is very less, about 40 
$\mathrm{ml}$ because there is a very less temperature difference between the glass surface and basin water also there is no spray of water. After that, there is a continuous spray of water from 16:00 hrs. to 16:30 hrs. to maintain temperature difference, due to the spray of water the temperature difference is of $9.2^{\circ} \mathrm{C}$ at $14: 30$ hrs. then there is a production of $80 \mathrm{ml}$ of water in next 30 minute. Though the temperature of the water is higher at 15:30 hrs. $\left(54.7^{\circ} \mathrm{C}\right)$ as compared to $16: 30 \mathrm{hrs} .\left(48.4^{\circ} \mathrm{C}\right)$.

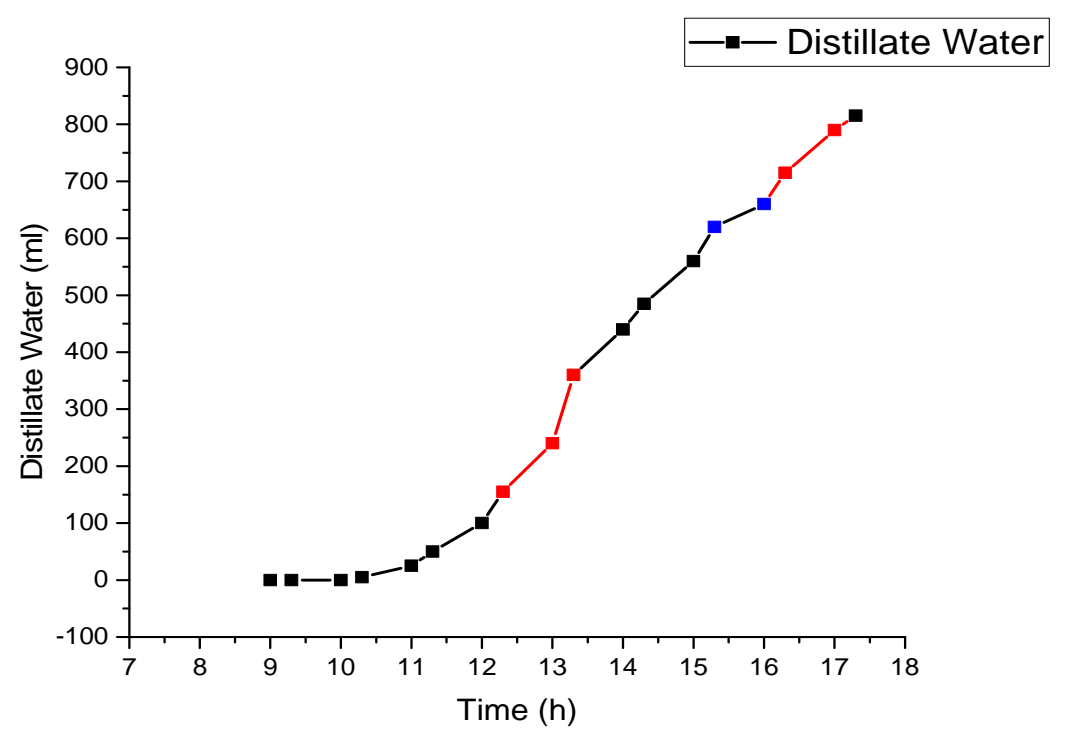

Fig. 10. Cumulative water production from one side of double slope, solar still and effect of water spray on production rate

Fig. 11 shows the variation of the temperature of the upper surfaces of glass with the variation of solar radiation and wind velocity. It can be seen from the Fig. that when the wind velocity increases the upper surfaces temperature of glass decreases. Between 11:00 hrs. to 11:30 hrs. as the wind velocity increases the south glass temperature decreases though the solar radiation is increased. The glass temperature is also decreased from 12:30 hrs. to 13:00 hrs. because of wind velocity increases, but the temperature decreases slightly because solar radiation is maximum during this time of period. The glass temperature also decreases from 16:00 hrs. to $16: 30$ hrs. for a small increment of velocity because solar radiation is minimum during this time. Due to this the water and glass temperature increases and production rate of solar still unit increase.

Thus, the wind velocity and solar radiation are the major parameters for temperature variation of the glass surface. The temperature of the glass surface is more affected after afternoon period because solar radiation is minimum and it is less affected before afternoon period because solar radiation is maximum during this period.

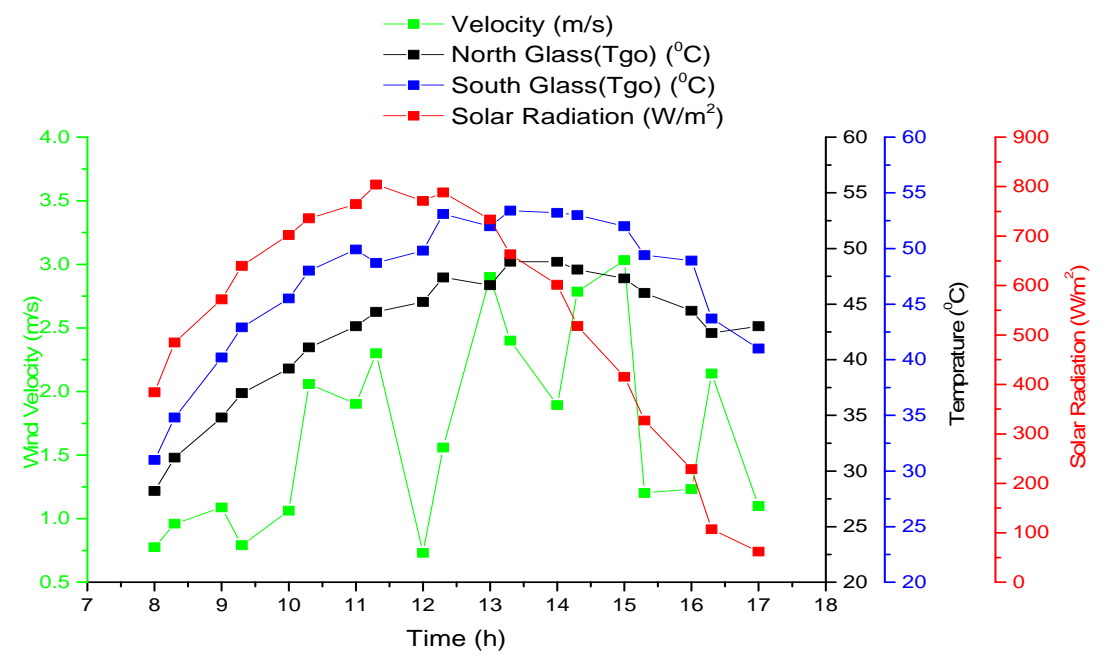

Fig. 11. The temperature variation of upper glass surfaces with variation of solar radiation and wind velocity

The Fig. 12 and 13 shows the Comparison of calculated and measured distillate output at $2 \mathrm{~cm}$ and $4 \mathrm{~cm}$ water depth respectively. (Dunkle's model is used for theoretical calculations and it is given in Appendix-A) 


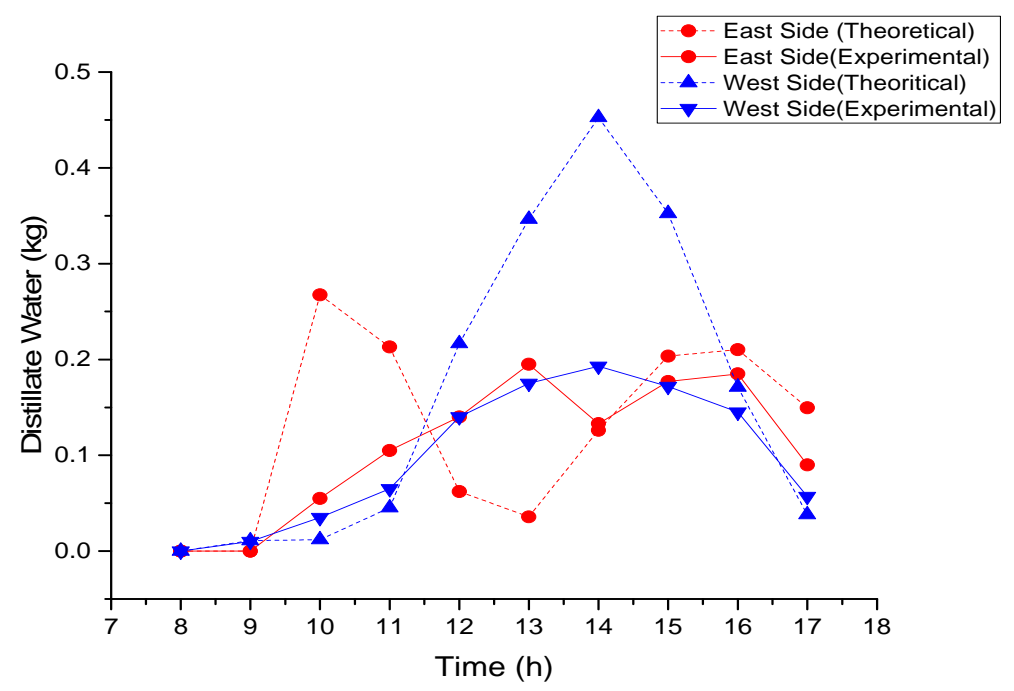

Fig. 12. Comparison of calculated and measured distillate output at $2 \mathrm{~cm}$ water depth

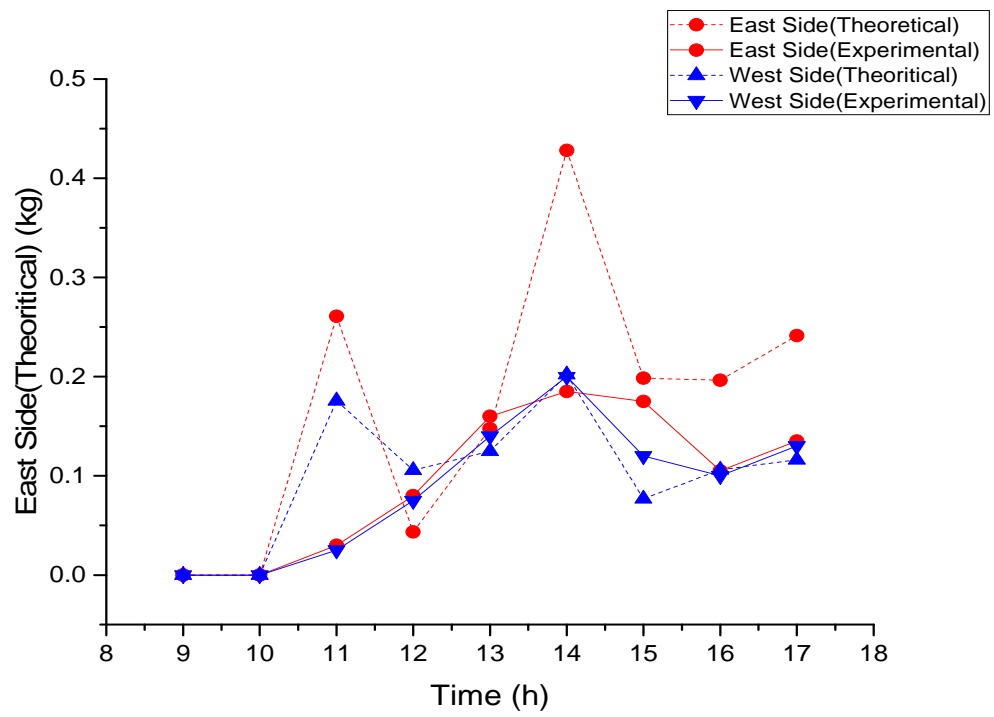

Fig. 13. Comparison of calculated and measured distillate output at $4 \mathrm{~cm}$ water depth

\section{Conclusions}

1. For same water depth, the North-South orientation gives the maximum temperature for basin water. It is found to be $15.61 \%$ higher temperature of basin water for North-South orientation of still as compared to East-West orientation when water depth is $2 \mathrm{~cm}$ (from 8:00 hrs. to 17:00 hrs.). The East-West orientation production of solar still is found $51.54 \%$ higher than North-south orientation for $4 \mathrm{~cm}$ water depth.

2. The production of solar still increases with the decrease in water mass (depth of water) in the basin. It is found that the production of distilled water is $20.46 \%$ higher for $2 \mathrm{~cm}$ water depth as compared to $4 \mathrm{~cm}$ water depth from 8:00 hrs. to 17:00 hrs.

3. The rate of production increases with an increase in solar radiation and also increase in wind velocity up to critical value.

4. The rate of production increases with proper water spray on glass surface because it maintains a good temperature difference between water and glass surface, due to this the rate of condensation increases. It has been found that there is a production of $40 \mathrm{ml}$ for $3^{\circ} \mathrm{C}$ temperature difference (from 15:00 hrs. to 15:30 hrs.) and after spraying water there is a production of $75 \mathrm{ml}$ when temperature difference is of $9.2^{\circ} \mathrm{C}$ ( from $16: 30$ hrs. to 17:00 hrs.).

\section{ACKNOWLEDGMENT}

This work was supported in part by a grant from the TEQIP II at KNIT Sultanpur. 


\section{REFERENCES}

[1] G. Singh, S. Kumar, and G. N. Tiwari, "Design, fabrication and performance evaluation of a hybrid photovoltaic thermal (PVT) double slope active solar still,” DES, vol. 277, no. 1-3, pp. 399-406, 2011.

[2] K. K. Murugavel, K. K. S. K. Chockalingam, and K. Srithar, "An experimental study on single basin double slope simulation solar still with thin layer of water in the basin,” vol. 220, pp. 687-693, 2008.

[3] T. Rajaseenivasan, T. Elango, and K. K. Murugavel, "Comparative study of double basin and single basin solar stills Dimensions are in mm,” DES, vol. 309, pp. 27-31, 2013.

[4] V. K. Dwivedi and G. N. Tiwari, "Comparison of internal heat transfer coefficients in passive solar stills by different thermal models: An experimental validation,” Desalination, vol. 246, no. 1-3, pp. 304-318, 2009.

[5] P. Kalita, A. Dewan, and S. Borah, “A review on recent developments in solar distillation units," Sadhana - Acad. Proc. Eng. Sci., vol. 41, no. 2, pp. 203-223, 2016., 2009.

[6] T. Elango and K. Kalidasa Murugavel, "The effect of the water depth on the productivity for single and double basin double slope glass solar stills,” Desalination, vol. 359, pp. 82-91, 2015.

[7] A. Metha, A. Vyas, N. Bodar, and D. Lathiya, “Design of Solar Distillation System,” Int. J. Adv. Sci. Technol., vol. 29, no. April, pp. 67-74, 2011.

[8] T. Rajaseenivasan and K. Kalidasa Murugavel, “Theoretical and experimental investigation on double basin double slope solar still,” Desalination, vol. 319, pp. 25-32, 2013.

[9] M. S. Malik, M.A.S.; Kumar, A.; Sodha, “Solar Distillation,” Pergamon Press. Oxford, UK, 1982.

[10] Z. M. Omara, M. A. Eltawil, and E. A. Elnashar, "A new hybrid desalination system using wicks / solar still and evacuated solar water heater," DES, vol. 325, pp. 56-64, 2013.

[11] A. A. Al-Karaghouli and W. E. Alnaser, "Performances of single and double basin solar-stills,” Appl. Energy, vol. 78, no. 3, pp. 347354, 2004.

[12] M. M. Morad, H. A. M. El-Maghawry, and K. I. Wasfy, "Improving the double slope solar still performance by using flat-plate solar collector and cooling glass cover,” Desalination, vol. 373, pp. 1-9, 2015.

[13] M. Zeroual, H. Bouguettaia, D. Bechki, S. Boughali, B. Bouchekima, and H. Mahcene, "Experimental investigation on a double-slope solar still with partially cooled condenser in the region of Ouargla (Algeria).,” Energy Procedia, vol. 6, pp. 736-742, 2011.

[14] V. K. Dwivedi and G. N. Tiwari, "Experimental validation of thermal model of a double slope active solar still under natural circulation mode,” Desalination, vol. 250, no. 1, pp. 49-55, 2010.

[15] M. Castillo-Téllez, I. Pilatowsky-Figueroa, Á. Sánchez-Juárez, and J. L. Fernández- Zayas, "Experimental study on the air velocity effect on the efficiency and fresh water production in a forced convective double slope solar still,” Appl. Therm. Eng., vol. 75, pp. 1192-1200, 2015.

[16] K. A. and Y. P. Y. G.N. Tiwari, K. Mukherjee, “Comparison of various designs of solar stills,” vol. 60, pp. 191-202, 1986.

\section{Abbreviations}

DSSS- Double Slope Solar Still

TDS- Total dissolved solids

ppm- Parts per million

SRRA- Solar Radiation Resource Assessment

E-W- East-West Orientation

N-S- North-South Orientation

\section{List of Symbols}

$\bullet$

Rate of Convective heat transfer from water to glass cover, $\mathrm{W} / \mathrm{m}^{2}$

$h_{c w} \quad$ Convective heat transfer coefficient from water to condensing cover, $\mathrm{W} / \mathrm{m}^{2}{ }^{\circ} \mathrm{C}$

$\dot{q}_{e w} \quad$ Rate of evaporative heat transfer from water to glass cover $\mathrm{W} / \mathrm{m}^{2}$

$h_{\text {ew }} \quad$ Evaporative heat transfer coefficient, $\mathrm{W} / \mathrm{m}^{2 \circ} \mathrm{C}$

-

$q_{r w} \quad$ Rate of radiative heat transfer from water to glass cover $\mathrm{W} / \mathrm{m}^{2}$

$h_{r w} \quad$ Radiative heat transfer coefficient, $\mathrm{W} / \mathrm{m}^{2 \circ} \mathrm{C}$

$\varepsilon_{\text {eff }} \quad$ Effective emissivity of water and glass surface

$\sigma \quad$ Stefan Boltzmann constant $\left(5.67 \times 10^{-8} \mathrm{~W} / \mathrm{m}^{2} \mathrm{~K}^{4}\right)$

$\varepsilon_{g} \quad$ Emissivity of glass

$\varepsilon_{w} \quad$ Emissivity of water 


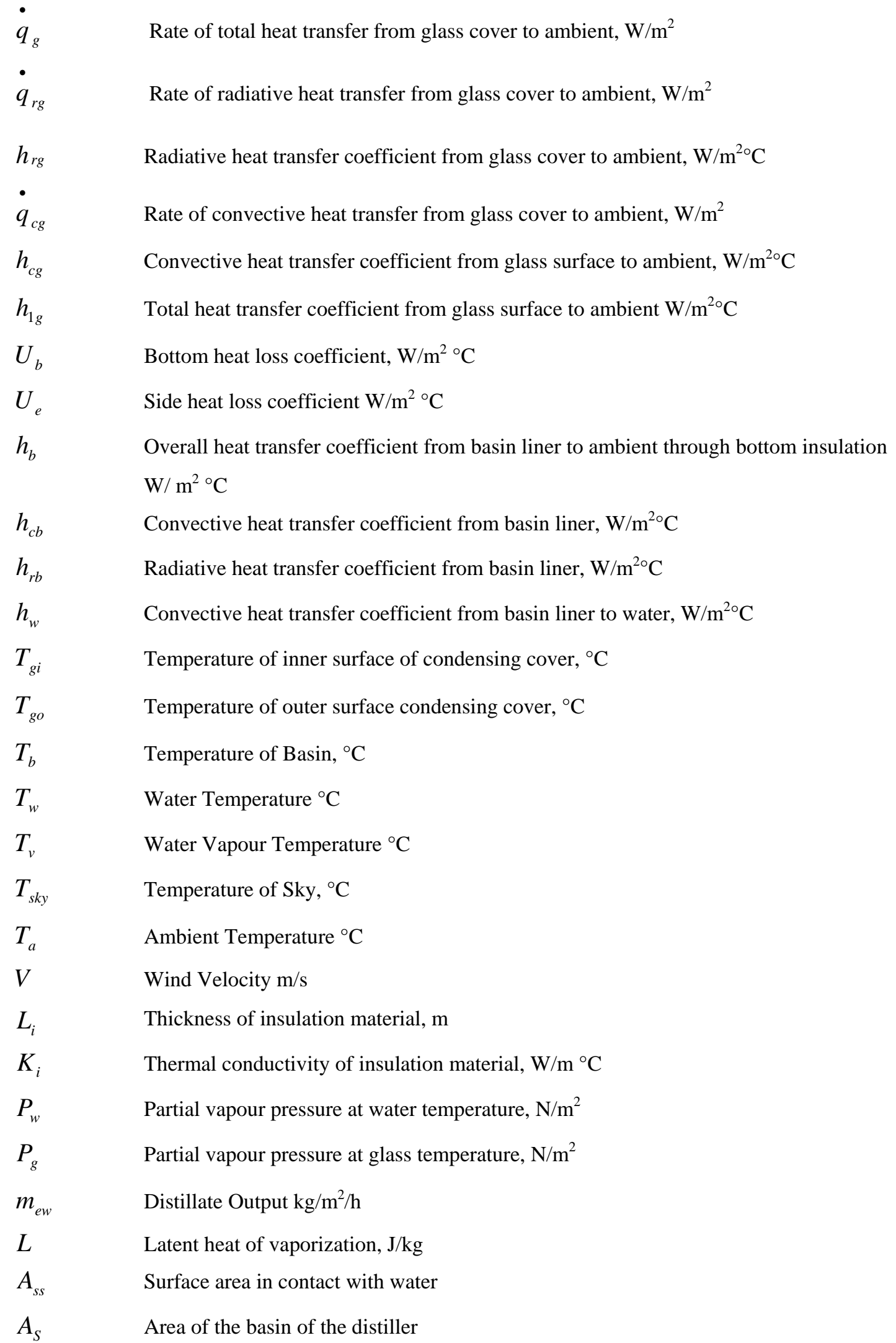

\section{Subscripts}

i : : Inner surface of glass

o : : Outer surface of glass 


$\begin{array}{lll}\text { a } & : & \text { Ambient air } \\ \text { w } & : & \text { Basin water } \\ \mathrm{g} & : & \text { Glass cover surface } \\ \mathrm{b} & : & \text { Basin liner } \\ \mathrm{v} & : & \text { Water vapour } \\ \mathrm{C} & : & \text { Convection } \\ \mathrm{r} & : & \text { Radiation } \\ \mathrm{e} & : & \text { Evaporation } \\ \mathrm{E} & : & \text { East side } \\ \mathrm{W} & : & \text { West side } \\ \mathrm{N} & : & \text { North side } \\ \mathrm{S} & : & \text { South side }\end{array}$

\section{APPENDIX-A}

Calculation for $h_{c w}, h_{e w}$ and $m_{e w^{-}}$

TABLE I. East Glass

\begin{tabular}{|c|c|c|}
\hline Time & $T_{w}\left({ }^{\circ} \mathrm{C}\right)$ & $T_{g i}\left({ }^{\circ} \mathrm{C}\right)$ \\
\hline $12.00-13.00$ & 57.20 & 52.73 \\
\hline $14.00-15.00$ & 57.07 & 51.33 \\
\hline $15.00-16.00$ & 55.53 & 49.47 \\
\hline
\end{tabular}

TABLE II. West Glass

\begin{tabular}{|c|c|c|}
\hline Time & $T_{w}\left({ }^{\circ} \mathrm{C}\right)$ & $T_{g i}\left({ }^{\circ} \mathrm{C}\right)$ \\
\hline $12.00-13.00$ & 57.20 & 53.30 \\
\hline $13.00-14.00$ & 57.57 & 51.87 \\
\hline $14.00-17.00$ & 51.80 & 47.20 \\
\hline
\end{tabular}

Calculation for $12.00-13.00$ when $T_{w}=57.20{ }^{\circ} \mathrm{C}$ and $T_{g i}=52.73{ }^{\circ} \mathrm{C}\left(T_{g}\right)$

From equation no. 25-

$$
m_{e w}=\frac{\dot{q}_{e w}}{L} 3600 \mathrm{~kg} / \mathrm{m}^{2} / \mathrm{h}
$$

From equation no. 26 -

$$
\begin{aligned}
& L=2.4935 \times 10^{6}\left[1-9.4779 \times 10^{-4} T+1.3132 \times 10^{-7} T^{2}-4.7974 \times 10^{-9} T^{3}\right\rfloor \\
& L=2.4935 \times 10^{6}\left[1-9.4779 \times 10^{-4} \times 57.20+1.3132 \times 10^{-7} \times 57.20^{2}-4.7974 \times 10^{-9} \times 57.20^{3}\right] \\
& L=2.3596 \times 10^{6} \mathrm{~J} / \mathrm{kg}
\end{aligned}
$$

The value of $\left(h_{e w}\right)$ from equation no.23 is given by-

$$
h_{e w}=16.273 \times 10^{-3} h_{c w} \frac{\left(P_{w}-P_{g}\right)}{\left(T_{w}-T_{g}\right)}
$$

The value of $P_{w}$ and $P_{g}$ are given by equation no. 24- 


$$
\begin{aligned}
& P_{g}=\exp \left[25.317-\frac{5144}{\left(T_{g i}+273\right)}\right] \\
& P_{w}=\exp \left[25.317-\frac{5144}{\left(T_{w}+273\right)}\right] \\
& P_{g}=\exp \left[25.317-\frac{5144}{(52.73+273)}\right] \\
& P_{g}=13697.12254 \mathrm{~N} / \mathrm{m}^{2} \\
& \text { And } P_{w}=\exp \left[25.317-\frac{5144}{(57.20+273)}\right]
\end{aligned}
$$

$$
P_{g}=16959.14829 \mathrm{~N} / \mathrm{m}^{2}
$$

The convective heat transfer coefficient is obtained by equation no. 18-

$$
h_{c w}=0.0884\left(\Delta T^{*}\right)^{\frac{1}{3}}
$$

Where $\Delta T^{*}=\left[\left(T_{w}-T_{g}\right)+\frac{\left(P w-P_{g}\right)(T w+273.15)}{268.9 \times 10^{3}-P w}\right]$

$$
\begin{aligned}
\Delta T^{*} & =\left[(57.20-52.73)+\frac{(16959.14829-13697.12254)(57.20+273.15)}{268.9 \times 10^{3}-16959.14829}\right] \\
\Delta T^{*} & =8.7419
\end{aligned}
$$

Putting the value of $\Delta T^{*}$ in above equation we get-

$$
\begin{aligned}
& h_{c w}=0.0884(8.7419)^{\frac{1}{3}} \\
& h_{c w}=1.82105 \mathrm{~W} / \mathrm{m}^{2} \mathrm{~K}
\end{aligned}
$$

Putting the value of $h_{e w}, P_{w}, P_{g}, T_{w}$ and $T_{g}$ in above equation-

$$
\begin{aligned}
& h_{e w}=16.273 \times 10^{-3} h_{c w} \frac{\left(P_{w}-P_{g}\right)}{\left(T_{w}-T_{g}\right)} \\
& h_{e w}=16.273 \times 10^{-3} \times 1.82105 \frac{(16959.14829-13697.12254)}{(57.20-52.73)} \\
& h_{e w}=21.6418 \mathrm{~W} / \mathrm{m}^{2} \mathrm{~K}
\end{aligned}
$$

Putting the value of $h_{e w}, T_{g}, T_{w}$ and $L$ in above equation-

$$
\begin{aligned}
& m_{e w}=\frac{\dot{q}_{e w}}{L} 3600 \mathrm{~kg} / \mathrm{m}^{2} / \mathrm{h} \\
& m_{e w}=\frac{h_{e w}\left(T_{w}-T_{g}\right)}{L} 3600
\end{aligned}
$$




$$
\begin{aligned}
& m_{e w}=\frac{21.6418(57.20-52.73)}{2.3596 \times 10^{6}} 3600 \\
& m_{e w}=0.14749 \mathrm{~kg} / \mathrm{m}^{2} / \mathrm{h}
\end{aligned}
$$

Similarly for other temperatures-

TABLE III. East Glass

\begin{tabular}{|c|c|c|c|c|c|c|}
\hline Time & $T_{w}\left({ }^{\circ} \mathrm{C}\right)$ & $T_{g i}\left({ }^{\circ} \mathrm{C}\right)$ & $\begin{array}{c}h_{c w} \\
\left(W / m^{2} K\right)\end{array}$ & $\begin{array}{c}h_{e w} \\
\left(W / m^{2} K\right)\end{array}$ & $\begin{array}{c}m_{e w}\left(\mathrm{~kg} / \mathrm{m}^{2} / \mathrm{h}\right) \\
\text { Theoretical }\end{array}$ & $\begin{array}{c}m_{e w}\left(\mathrm{~kg} / \mathrm{m}^{2} / \mathrm{h}\right) \\
\text { Experimental }\end{array}$ \\
\hline $12.00-13.00$ & 57.20 & 52.73 & 1.82105 & 21.6418 & 0.14749 & 0.160 \\
\hline $14.00-15.00$ & 57.07 & 51.33 & 1.96883 & 25.5628 & 0.19835 & 0.175 \\
\hline $15.00-16.00$ & 55.53 & 49.47 & 1.98101 & 21.2459 & 0.19634 & 0.165 \\
\hline
\end{tabular}

TABLE IV. West Glass

\begin{tabular}{|c|c|c|c|c|c|c|}
\hline Time & $\begin{array}{c}T_{w} \\
\left({ }^{\circ} \mathrm{C}\right)\end{array}$ & $\begin{array}{c}T_{g i} \\
\left({ }^{\circ} \mathrm{C}\right)\end{array}$ & $\begin{array}{c}h_{c w} \\
\left(W / m^{2} K\right)\end{array}$ & $\begin{array}{c}h_{e w} \\
\left(W / m^{2} K\right)\end{array}$ & $\begin{array}{c}m_{e w}\left(\mathrm{~kg} / \mathrm{m}^{2} / \mathrm{h}\right) \\
\text { Theoretical }\end{array}$ & $\begin{array}{c}m_{e w}\left(\mathrm{~kg} / \mathrm{m}^{2} / \mathrm{h}\right) \\
\text { Experimental }\end{array}$ \\
\hline $12.00-13.00$ & 57.20 & 53.30 & 1.74381 & 20.9639 & 0.12474 & 0.140 \\
\hline $14.00-15.00$ & 57.57 & 51.87 & 1.97286 & 23.2204 & 0.20201 & 0.200 \\
\hline $15.00-16.00$ & 51.80 & 47.20 & 1.76667 & 16.6471 & 0.11622 & 0.130 \\
\hline
\end{tabular}

